\title{
Komputerisasi Sistem Analisis Data Mahasiswa Berbasis Client - Server (Studi Eksperimen pada Universitas Dhyana Pura)
}

\author{
I Gusti Ngurah Alit Widana Putra ${ }^{1}$ I Gede Neil Prajamukti Wardhana ${ }^{2}$ \\ Prodi Teknik Informatika, Fakultas Kesehatan Sains dan Teknologi ${ }^{1}$ \\ Prodi Sastra Inggris, Fakultas Manajemen dan Humaniora ${ }^{2}$ \\ Universitas Dhyana Pura ${ }^{12}$ \\ alit_wp@yahoo.com¹ neilwardhana86@gmail.com²
}

\begin{abstract}
This study is aimed to apply the information technology that processing of students data University of Dhyana Pura. Besides of the data analysis process also to the input process of student biodata. The process input of student biodata in University of Dhyana Pura is still conventional that using a paper that is hand write to all of students. Then, to make the analysis data is still conventional using Microsoft Excel. Indeed, the student staff must read the students biodata one by one and its means consume a lot of time and energy. Nowadays in the developing era of information technology, it can be solved by creating a new system that can work automatically and go green because it can minimize using papers. This research will be conducted in University of Dhyana Pura.This research is quasi experiment with the design is post-test only control group design. The method that is used to build this system is SDLC (Systems Development Life Cycle). SDLC is the pattern to develop the software with the steps are:planning, analysis, design, implementation, testing and maintenance. Using the ClientServer basis, it can probably this system accessing by network. The result of this research is the application of Client-Server basis to help the students collecting data process, to input biodata electronically and analysis data in University of Dhyana Pura more effective and efficient
\end{abstract}

Keywords: application, client-server, go-green.

\begin{abstract}
ABSTRAK
Penelitian ini bertujuan untuk menerapkan teknologi informasi pada proses analisis data mahasiswa Universitas Dhyana Pura. Selain pada proses analisis data juga pada proses input biodata mahasiswa.Pada Universitas Dhyana Pura proses input biodata mahasiswa masih bersifat konvensional yang menggunakan selembar kertas form biodata yang harus ditulis tangan oleh semua mahasiswa. Pada jaman kemajuan teknologi informasi hal tersebut tentunya bisa diatasi untuk dibuatkan sebuah sistem yang dapat bekerja otomatis dan lebih bersifat $g o$ green karena dapat mengurangi penggunaan kertas.Penelitian ini dilaksanakan di Universitas Dhyana Pura.Jenis penelitian ini adalah quasi eksperiment, dengan rancangan post-test only control group design. Sampel yang digunakan adalah beberapa data mahasiswa yang diperoleh dari bagian kemahasiswaan dalam bentuk form biodata dari kertas pada Universitas Dhyana Pura.Pengumpulan data dilakukan dengan observasi terstruktur dan tidak terstruktur.Teknik analisa yang digunakan dalam penelitian ini adalah analisis varians (anava) satu jalur.Metode yang digunakan untuk membangun sistem tersebut adalah SDLC (Systems Development Life Cycle).SDLC merupakan pola yang diambil dalam mengembangkan software yang terdiri dari tahap-tahap : planning, analysis, design, implementation, testing and maintenance. Hasil yang diharapkan dalam penelitian ini adalah sebuah aplikasi berbasis client - server untuk membantu proses pengolahan data, menginput biodata secara elektronik dan analisis data mahasiswa pada Universitas Dhyana Pura agar menjadi lebih efektif dan efisien.
\end{abstract}

Kata Kunci: aplikasi client - server, analisis mahasiswa, go green. 


\section{PENDAHULUAN}

\section{Latar Belakang Penelitian}

Perkembangan teknologi database saat ini sangat pesat, banyak bentuk-bentuk yang dulu hanya mempunyai teknologi sebagai tempat penyimpanan data yang terdiri dari field-field, record dan diolah serta ditampilkan menjadi informasi dalam berbagai format tampilan yang sederhana, namun kini bermula dari bentuk yang sederhana tersebut telah didapatkan suatu metode untuk menampilkan suatu database yang berguna untuk menganalisa data untuk suatu keperluan tertentu. Dengan memanfaatkan relational database yang sudah ada maka didapat suatu cara untuk mengantisipasi kebutuhan guna menganalisa data secara cepat untuk membantu mendapatkan keputusan dalam suatu organisasi.

Nama Dhyana Pura telah dipakai sejak berdirinya tahun 1987 sebagai Pusat Pendidikan dan Latihan Pariwisata Dhyana Pura yang selalu berusaha untuk mempertahankan kualitas pendidikan dan kualitas lulusannya. Pada 1987, didirikan Pusat Pendidikan dan Latihan Pariwisata (PPLP) Dhyana Pura dengan menyelenggarakan program pelatihan perhotelan bertempat di Hotel Dhyana Pura, Jalan Dhyana Pura, Seminyak, Kuta, Bali. Pada 1994 PPLP Dhyana Pura menempati kampus baru di atas lahan seluas 1,5 ha bertempat di Jalan Raya Padangluwih, Tegaljaya, Dalung, Kuta, Bali. Pada 1998 Menambah bangunan kampus diberi namaKampus $\mathrm{B}$ dan $\mathrm{C}$ berlantai tiga dan empat dengan fungsi sebagai kampus utama, perkantoran, dan tempat praktek berbagai program terkait bidang pendidikan dan pelatihan masingmasing. Pada Tahun 2001, Yayasan Dhyana Pura mendirikan Sekolah Tinggi Ilmu Manajemen Dhyana Pura. Pada tahun 2011, perubahan bentuk Sekolah Tinggi Ilmu Manajemen Dhyana Pura yang diselenggarakan oleh Yayasan Dhyana Pura Kabupaten Badung Provinsi Bali menjadi Universitas Dhyana Pura di Kabupaten Badung Provinsi Bali yang diselenggarakan oleh Yayasan Dhyana Pura Bali dengan : SK MENTERI PENDIDIKAN NASIONAL REPUBLIK INDONESIA: NO. 142/E/0/2011 TERTANGGAL 7 JULI 2011.

Universitas Dhyana Pura memiliki 2 fakultas yaitu Fakultas Ekonomi dan Humaniora dan Fakultas Kesehatan, Sains dan Teknologi. Fakultas Ekonomi dan Humaniora memiliki beberapa Program Studi yaitu : S1-Manajemen, S1-Psikologi, S1-PAUD, S1-PKK, S1-Sastra Inggris dan D3-Manajemen Pemasaran. Fakultas Kesehatan, Sains dan Teknologi memiliki beberapa Program Studi yaitu : S1-Perekam dan Informasi Kesehatan, S1-Kesehatan Masyarakat, S1-Ilmu Gizi, S1-Fisioterapi, S1-Biologi, S1-Sistem Informasi dan S1Teknik Informatika.

Berdasarkan data yang diperoleh penulis dari Universitas Dhyana Pura data mahasiswa masing-masing program studi dapat dilihat pada table berikut :

Tabel 1Jumlah Mahasiswa Semester I Tiap Program Studi Angkt. 2015-2016

\begin{tabular}{|c|c|c|}
\hline No & Nama Program Studi & Jumlah Mahasiswa \\
\hline 1 & S1-Manajemen & 198 \\
\hline 2 & S1-Sastra Inggris & 19 \\
\hline 3 & S1-Psikologi & 33 \\
\hline 4 & S1-PAUD & 4 \\
\hline 5 & S1-PKK & 5 \\
\hline 6 & D3-Manajemen Pemasaran & 3 \\
\hline 7 & S1-Fisioterapi & 53 \\
\hline 8 & S1-Perekam dan Informasi Kesehatan & 75 \\
\hline 9 & S1-Kesehatan Masyarakat & 24 \\
\hline 10 & S1-Ilmu Gizi & 32 \\
\hline 11 & S1-Biologi & 6 \\
\hline 12 & S1-Sistem Informasi & 5 \\
\hline 13 & S1-Teknik Informatika & 8 \\
\hline & Total & 465 \\
\hline
\end{tabular}


Dari data tersebut dapat diketahui bahwa jumlah mahasiswa pada Universitas Dhyana Pura tidak sedikit dan untuk melakukan proses analisis data menjadi tidak mudah karena Analisis yang dilakukan mencangkup beberapa kategori seperti : jenis kelamin, usia, golongan darah, tinggi badan, berat badan, alamat asal, alamat sekarang, social media, hobby, prestasi akademik dan non akademik, urutan kelahiran, agama, asal sekolah, riwayat kursus, pekerjaan orang tua, pendidikan orang tua, alamat orangtua.

Metode analisis data terhadap para mahasiswa yang ada masih menggunakan Microsoft Excel.Hal ini dirasa kurang efektif dan efisien karena dilihat dari banyaknya kategori yang dianalisis dan sulitnya dilakukan dokumentasi dan pengecekan jika diperlukan.

Aplikasi yang berbasis client-server dipilih untuk dikembangkan karena dengan Aplikasi Client-Server dapat meningkatkan pelayanan kepada masyarakat dalam hal pembayaran iuran bulanan bagi perusahaan. Sehingga pada aplikasi ini akan ada dua sisi yang bekerja yaitu sisi client dan sisi server. Sisi client adalah sebuah program aplikasi database yang dibuat dengan bahasa pemrograman delphi sedangkan sisi server adalah sebuah database server dan sebuah program aplikasi server.

Sistem yang terkomputerisasi merupakan metode yang dapat membantu memudahkan pekerjaan analisis data mahasiswa dan melakukan dokumentasi.Berdasarkan latar belakang di atas peneliti dalam penelitian ini tertarik dengan judul penelitian "Komputerisasi Sistem Analisis Data Mahasiswa Berbasis Client - Server (Studi Eksperimen pada Universitas Dhyana Pura)".

\section{Rumusan Masalah}

Sesuai dengan latar belakang yang dikemukakan di atas, penulis mengemukakan rumusan masalah sebagai berikut: "Bagaimana merancang dan membangun sistem informasi untuk membantu dalam proses pengolahan data dan analisis data mahasiswa pada Universitas Dhyana Pura?”.

\section{Batasan Masalah}

Agar dalam penelitian ini lebih terarah dan tidak terlalu meluas serta dapat mencapai sasaran yang diinginkan, maka permasalahan dibatasi pada hal-hal sebagai berikut :
1. Sistem yang dirancang tidak memiliki keamanan log-in karena digunakan langsung oleh pegawai administrasi dan tidak ada user yang lain.

2. Analisis yang bisa dilakukan sistem ini adalah sebatas pada data yang sudah dikumpulkan seperti : analisis jenis kelamin, analisis usia, analisis golongan darah, analisis tinggi badan, analisis berat badan, analisis alamat asal, analisis alamat sekarang, analisis social media, analisis hobi, analisis prestasi, analisis agama, analisis asal sekolah, analisis riwayat kursus, analisis pekerjaan orang tua, analisis pendidikan orang tua dan analisis alamat orang tua.

\section{Tujuan Penelitian}

Tujuan yang diharapkan dari penelitian ini adalah sebagai berikut :

Merancang dan membangun sistem informasi yang dapat membantu mengolah data dan melakukan analisis data mahasiswa pada universitas Dhyana Pura.

Dapat membantu pekerjaan pegawai administrasi untuk mengolah data dan menganalisis data mahasiswa.

\section{Manfaat Penelitian}

Penelitian ini diharapkan mempunyai manfaat dalam proses pengolahan data dan analisis data mahasiswa pada Universitas Dhyana Pura. Adapun manfaat penelitian ini adalah sebagai berikut:

- Mengetahui peran teknologi infor-masi dalam melakukan dokumentasi terhadap data mahasiswa.

- Dapat meningkatkan kualitas pela-yanan dalam hal proses analisis data mahasiswa karena proses analisis dihitung otomatis menggunakan komputer.

- Dapat meringankan pekerjaan pega-wai LP2M pada Universitas Dhyana Pura dalam hal pengolahan data mahasiswa.

- Hasil dari analisis data tersebut dapat digunakan untuk pengambilan keputusan yang berhubungan dengan kemahasiswaan. 


\section{MODEL, ANALISIS, DESAIN, DAN IMPLEMENTASI}

\section{Rancangan Penelitian}

Sistem informasi analisis data mahasiswa adalah sistem yang dirancang untuk membantu pekerjaan pegawai administrasi untuk mendapatkan informasi yang cepat dan akurat yang bisa digunakan sebagai bahan pertimbangan pengambilan suatu keputusan. Perangkat yang digunakan menganalisis kebutuhan sistem adalah diagram Unified Modeling Language (UML) yang dikembangkan menjadi kamus data yang berisi seluruh item data yang digunakan dalam sistem. Terdapat tiga tahap utama dalam perancangan sistem informasi, yaitu :

\section{- Subsistem data}

Data sistem disimpan dalam suatu data relasional.Kebutuhan sebuah basisdata ditentukan dari objek-objek yang terlibat dalam sistem, atribut masing-masing objek dan hubungannya.Kemudian dirancang struktur dari masing-masing tabel.

\section{Subsistem model}

Model yang digunakan dalam sistem informasi ini adalah model client-server.Client-server merupakn model sistem informasi yang lebih baik karena menawarkan pengolahan data yang terpisah antara sisi server dan sisi client.

\section{Subsistem dialog}

Dialog antarmuka pengguna merupakan komponen yang sangat penting sebagai penghubung antara user dengan sistem. Dialog yang digu-nakan dalam perancangan sistem informasi ini adalah :
a) Dialog menu
b) Dialog masukan/keluaran
c) Dialog laporan

\section{Model dan Desain Sistem}

Desain rancangan sistem informasi analisis data mahasiswa pada universitas dhyana pura adalah sebagai berikut yang digambarkan dalam diagram use case.

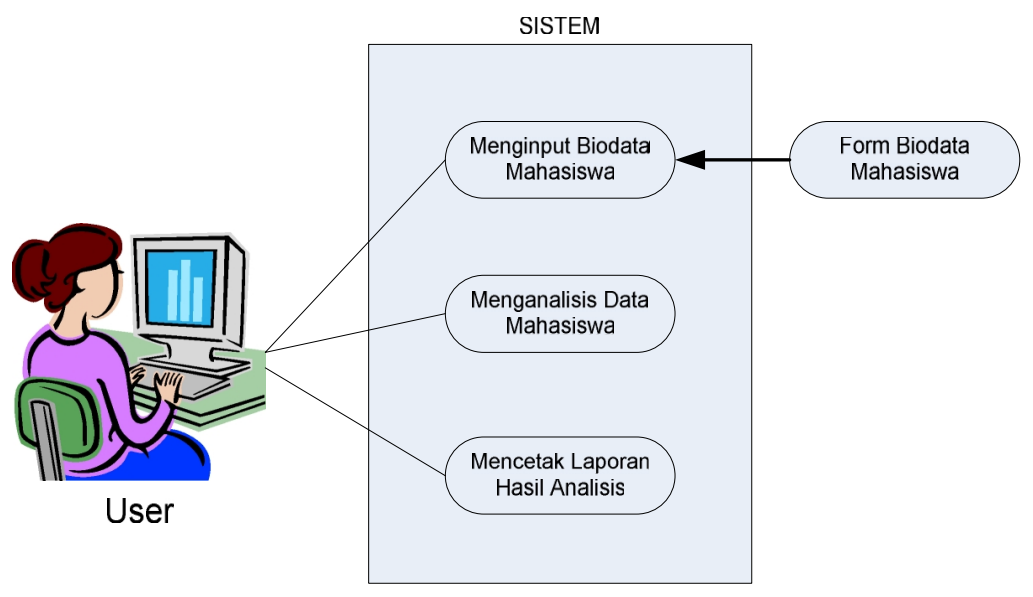

\section{Gambar 1.Use Case Sistem Informasi Analisa Data Mahasiswa}

Berdasarkan diagram pada gambar

1 dapat diidentifikasi kebutuhan sistem yang dibangun antara lain :

a) Sistem diharapkan mampu melakukan penginputan data mahasiswa dan data orangtua mahasiswa.

b) Sistem diharapkan mampu melakukan analisa data mahasiswa sesuai kategori yang ditentukan user.

c) Sistem diharapkan mampu mencetak laporan hasil analisis.
Data Jenis Data

Jenis data yang digunakan dalam perancangan sistem analisis data mahasiswa ini adalah data kuantitatif, ini didasarkan karena data yang dianalisa bersifat kuantitatif.

Sumber Data

Sumber data yang digunakan dalam sistem informasi ini adalah data sekunder, merupakan data yang bukan diusahakan sendiri pengumpulannya oleh peneliti. Data ini diperoleh dalam bentuk yang sudah jadi, sudah dikumpulkan, dan diolah oleh pihak 
lain bukan oleh peneliti. Data sekunder dalam penelitian ini adalah data hasil analisa mahasiswa yang dikerjakan secara konvensional.

\section{Cara Penelitian}

Penelitian dilakukan dengan menggunakan konsep sistem informasi. Adapun proses perancangan sistem yang nanti dilakukan adalah sebagai berikut :

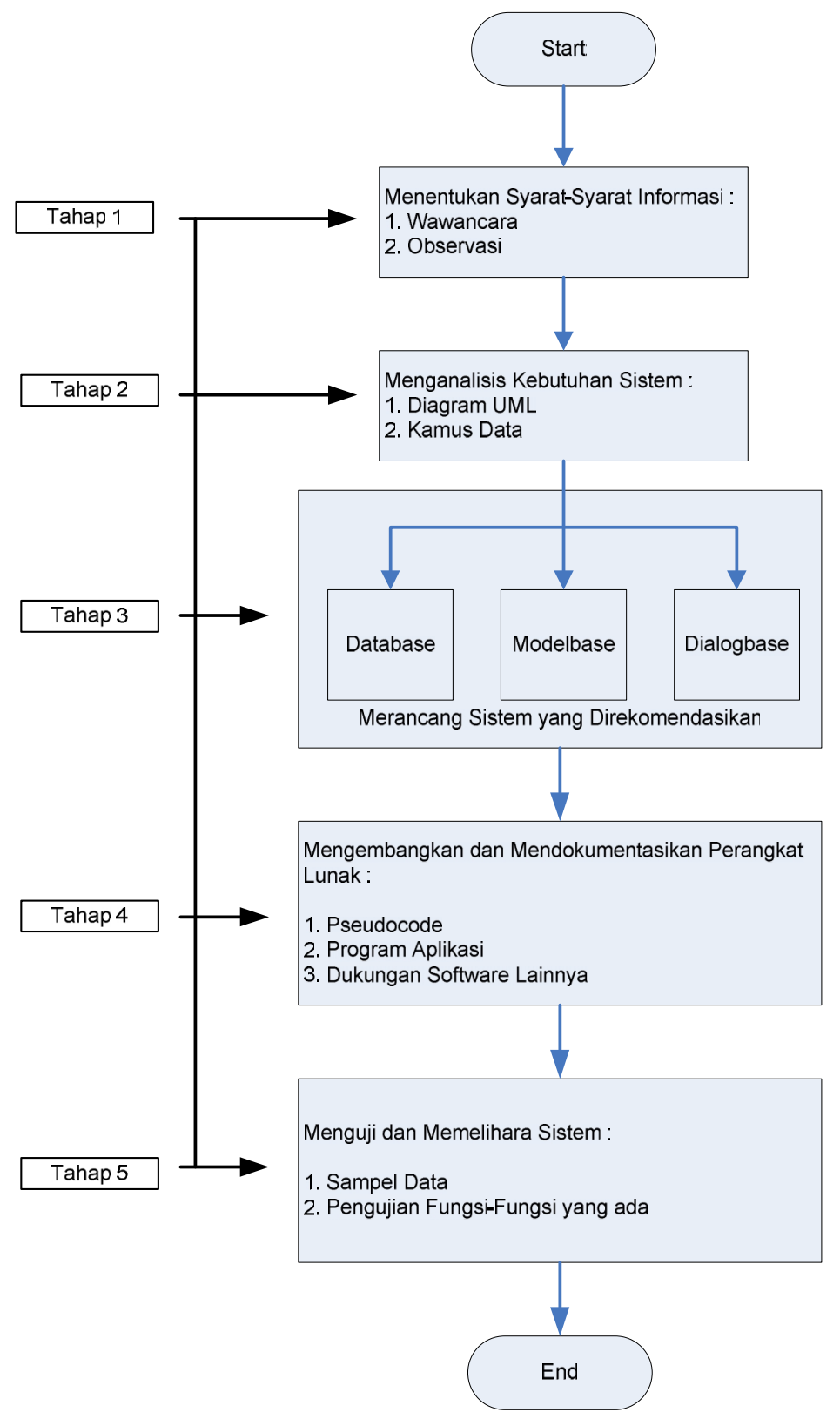

Gambar 2.Tahapan Perancangan Sistem Informasi Analisis Data Mahasiswa.

Identifikasi Masalah, Peluang dan Tujuan Berdasarkan hasil pengamatan yang dilakukan terhadap beberapa permasalahan yang ditemukan dalam proses analisis data mahasiswa yaitu :

- Metode analisa data yang digunakan saat ini masih menggunakan Microsoft Excel sehingga petugas mendapat kesulitan karena harus mendata satu persatu ke dalam Excel.

- Proses input data biodata mahasiswa masih menggunakan form kertas sehingga hal ini menyulitkan petugas saat akan membuat laporan karena harus mendata lagi ke komputer. 
- Kurang flesibel jika ingin menganalisa data mahasiswa secara menyeluruh.

- Memakan banyak waktu untuk membuat laporan hasil analisis.

- Dokumentasi yang kurang baik sehingga jika ingin dilakukan pencarian data maka akan menemui kesulitan.

Selain permasalahan tersebut terdapat juga beberapa peluang yang dapat meningkatkan kinerja proses analisis data mahasiswa, yaitu :

- $\quad$ Petugas tidak perlu lagi mendata satu persatu data mahasiswa untuk melakukan proses analisis karena sudah direkam oleh sistem komputer.

- Proses input biodata mahasiswa tidak lagi membutuhkan kertas karena langsung diinput menggunakan sistem komputer.

- Lebih fleksibel dalam hal pengelolaan data.

- Waktu bekerja menjadi lebih ringkas.

- Dokumentasi lebih terstruktur sehingga jika ingin mencari suatu data akan lebih cepat dan mudah.

\begin{abstract}
Analisis Kebutuhan Sistem
Berdasarkan syarat-syarat informasi yang dibutuhkan oleh sistem terdapat beberapa analisis yang telah dilakukan meliputi analisis kebutuhan pengguna, analisis proses, dan analisis data.
\end{abstract}

Analisis Kebutuhan Pengguna

Analisis kebutuhan pengguna dilakukan melalui wawancara dengan pengguna sistem. Hasil analisis digambarkan dengan menggunakan diagram use case yang menggambarkan fungsionalitas yang diharapkan dari sebuah sistem. Yang ditekankan adalah apa yang dikerjakan sistem dan bukan bagaimana sistem itu mengerjakan proses. Sebuah Use Case merepresentasikan sebuah interaksi antara aktor (pengguna) dengan sistem. Adapun diagram Use Case dari hasil analisis yang dilakukan yaitu terdapat dua aktor didalam sistem, administrator dan mahasiswa. Masing-masing aktor memiliki fungsi yang berbeda.

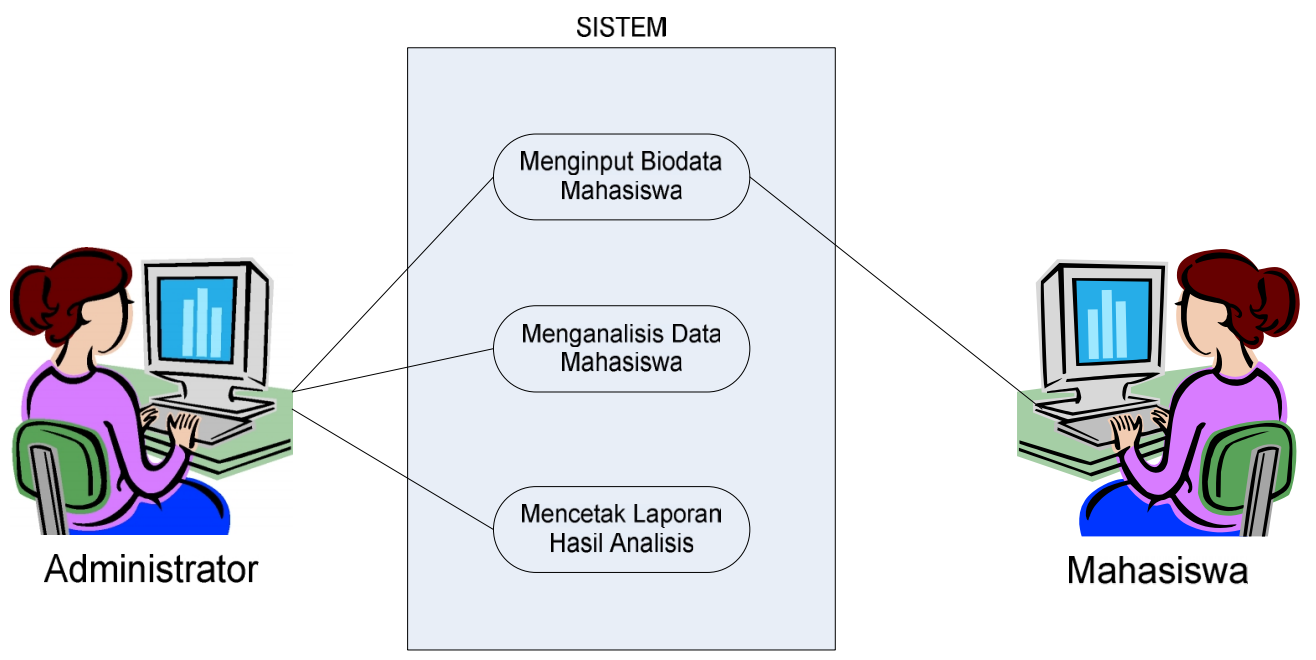

Gambar 3. Diagram Use Case Sistem Informasi Analisis Data Mahasiswa

Berdasarkan diagram Use Case pada gambar 3 dapat diidentifikasi kebutuhan fungsional dari penggunaan terhadap sistem informasi yang dirancang, antara lain :

- Menginput biodata mahasiswa Aktor yang dapat melakukan tugas mencetak laporan hasil analisis adalah administrator. Setelah administrator melakukan analisis data maka sistem akan memberikan pilihan untuk mencetak hasilnya.
- Menganalisis Data Mahasiswa

Aktor yang bisa melakukan tugas menganalisis data mahasiswa hanya administrator. Tugas menganalisis data mahasiswa yang dimaksud adalah menampilkan infor-masi tentang jumlah mahasiswa laki-laki dan perempuan masingmasing prodi, menam-pilkan informasi 
tentang golongan darah mahasiswa masingmasing prodi dan lain sebagainya.

- Mencetak laporan hasil analisis Aktor yang dapat melakukan tugas mencetak laporan hasil analisis adalah administrator. Setelah administrator melakukan analisis data maka sistem akan memberikan pilihan untuk mencetak hasilnya.

\section{Analisis Proses}

Hasil dari analisis kebutuhan pengguna menunjukkan terdapat beberapa proses yang terjadi pada sistem yang dirancang. Dalam pembahasan mengenai proses yang terjadi dalam sistem diterapkan penggunaan diagram UML yaitu diagram aktivitas dan diagram rangkaian/sekuensi. Adapun proses yang terjadi didalam sistem adalah sebagai berikut :

\section{- Proses pendataan biodata} mahasiswa

Proses ini bertujuan untuk menyimpan informasi tentang seorang mahasiswa. Adapun informasi yang disimpan adalah : nama lengkap, nama panggilan, nim, program studi, alamat sekarang, alamat asal, agama, social media, mobile phone, hobi, prestasi yang pernah diraih, asal sekolah, golongan darah, tinggi dan berat badan.

Proses pendataan ini pengguna memasukkan informasi biodata mahasiswa kedalam sistem. Kemudian sistem akan menyimpan kedalam basisdata. Adapun informasi yang disimpan adalah : nama lengkap, nama panggilan, nim, program studi, alamat sekarang, alamat asal, agama, social media, mobile phone, hobi, prestasi yang pernah diraih, asal sekolah, golongan darah, tinggi dan berat badan. Data yang telah tersimpan akan digunakan sebagai data untuk analisis. Aktivitas dari proses pendataan biodata mahasiswa digambarkan seperti gambar 4 berikut.

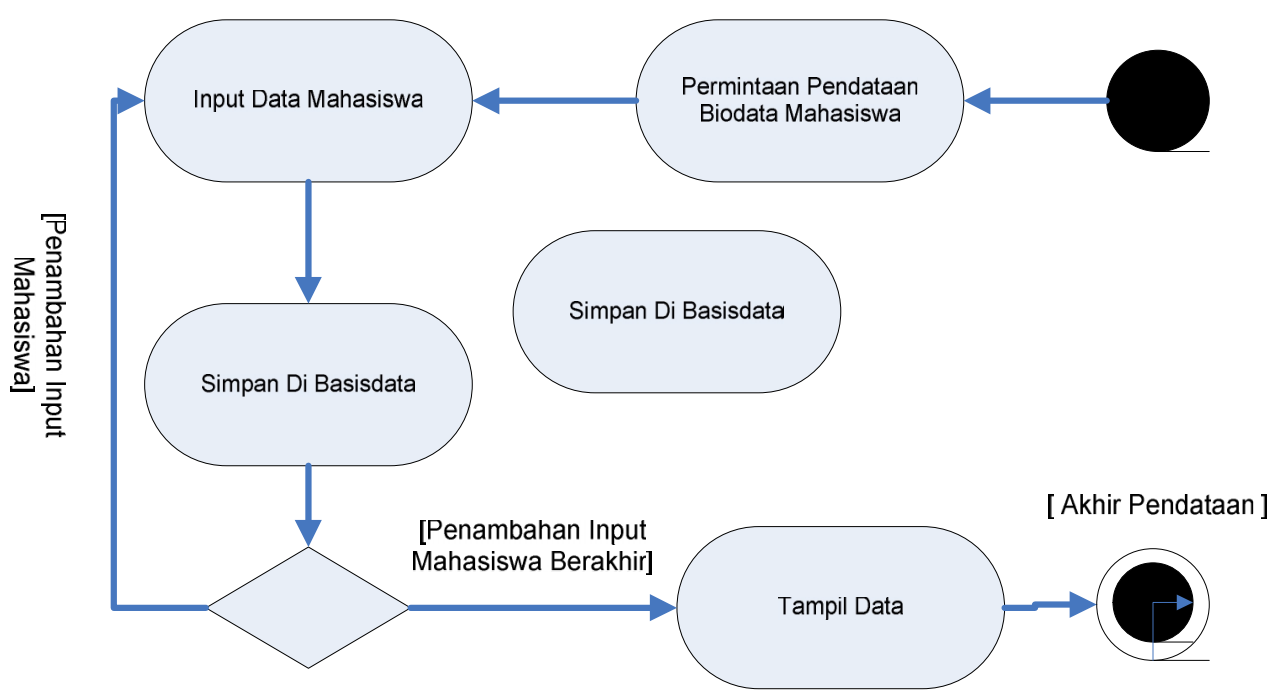

Gambar 4. Diagram Aktivitas Pendataan Mahasiswa

Gambar 4 merupakan diagram sekuensi yang menggambarkan interaksi antar objek di dalam dan disekitar sistem yang menjalankan skenario atau rangkaian langkah-langkah yang dilakukan sebagai respon dan event pada inputan pendataan biodata mahasiswa. Pengguna pada awalnya memberikan data inputan biodata mahasiswa, kemudian data inputanakan disimpan di objek entiti pada basisdata. Data yang sudah tersimpan ditampilkan lagi ke obyek antarmuka pengguna. 


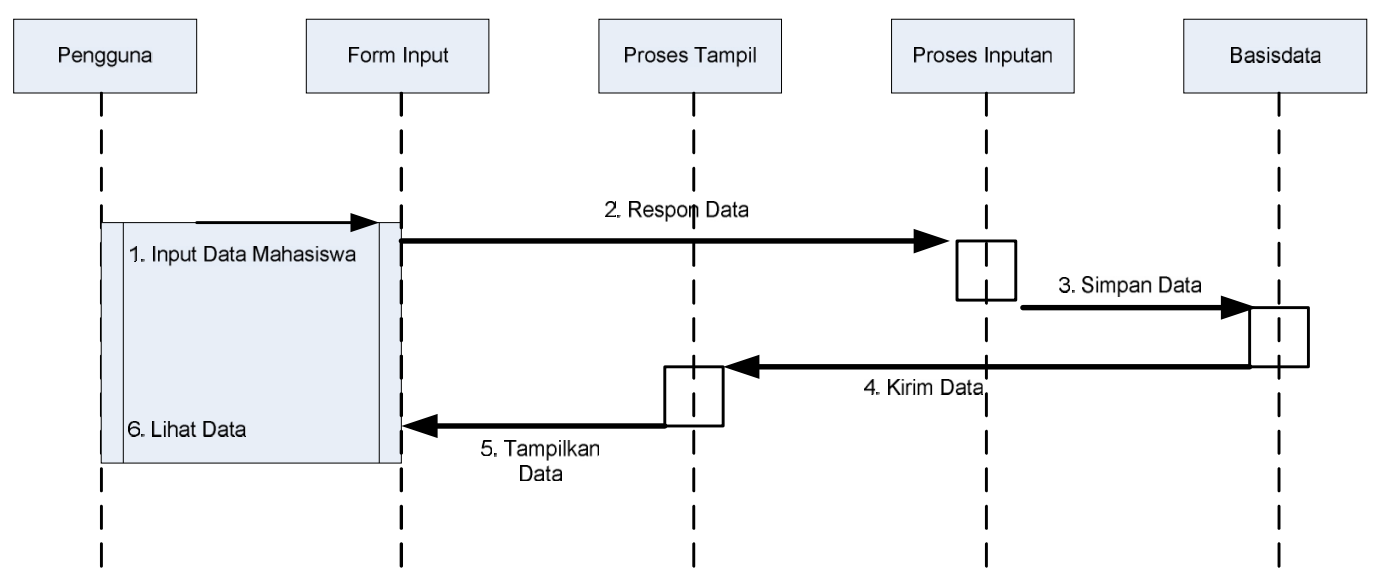

Gambar 5. Diagram Sekuensi Proses Pendataan Biodata Mahasiswa

\section{Perancangan Sistem}

Tahapan perancangan sistem informasi analisis data mahasiswa terdiri dari tiga tahapan utama yaitu :

1. Perancangan basisdata

2. Perancangan dialog antarmuka

3. Perancangan laporan

Tahap pertama komponen sistem informasi berpedoman pada tahap analisis sistem yang telah dilakukan sebelumnya.

\section{Perancangan Basis Data}

Model basisdata yang dirancang dalam sistem menggunakan model data logika/konseptual dan model data fisik.Sebelum membangun model data tersebut terlebih dahulu ditentukan objek yang terdapat dalam sistem.Kandidat objekobjek ini telah teridentifikasi sebelumnya melalui kamus data. Objek-objek tersebut antara lain :

1. Fakultas

2. Hobi

3. Kabupaten

4. Kategori hobi

5. Kategori prestasi

6. Mahasiswa

7. Pekerjaan

8. Prestasi

9. Program studi

10. Provinsi

Setelah penentuan objek, selanjutnya objek-objek tersebut diorganisir dan diidentifikasi hubungan antar objek. Menurut kurata(1996), terdapat 3 jenis dasar hubungan antar objek, yaitu :
1. Subkelas

Merupakan hubungan antara kelas objek dengan kelas objek diatasnya, dimana objek-objek ini memiliki properti dan perilaku kelas diatasnya. Hubungan ini diidentifikasi dengan menggunakan klausa "adalah(is a)".

2. Container (wadah)

Merupakan hubungan yang terjadi karena suatu objek terbentuk dari objek lain. Hubungan diidentifikasi dengan menggunakan bahasa klausa "memiliki (has a)"

3. Kolaborator

Merupakan hubungan yang terjadi apabila objek perlu menggunakan objek lain untuk tujuan tertentu. Hubungan ini diidentifikasi dengan menggunakan klausa "memakai (use)"

Hubungan yang terjadi antara objek pada perancangan sistem informasi ini adalah hubungan container dan kolaborator.Untuk menggambarkan hubungan antar objek tersebut, selanjutnya dibangun model logika dari basisdata.Model data logika atau model data konseptual menggambarkan struktur logis dari basisdata, serta kardinalitas antar objek. Adapun model data konseptual dari basisdata Sistem Informasi analisis data mahasiswa ditunjukkan pada gambar 6 berikut ini : 

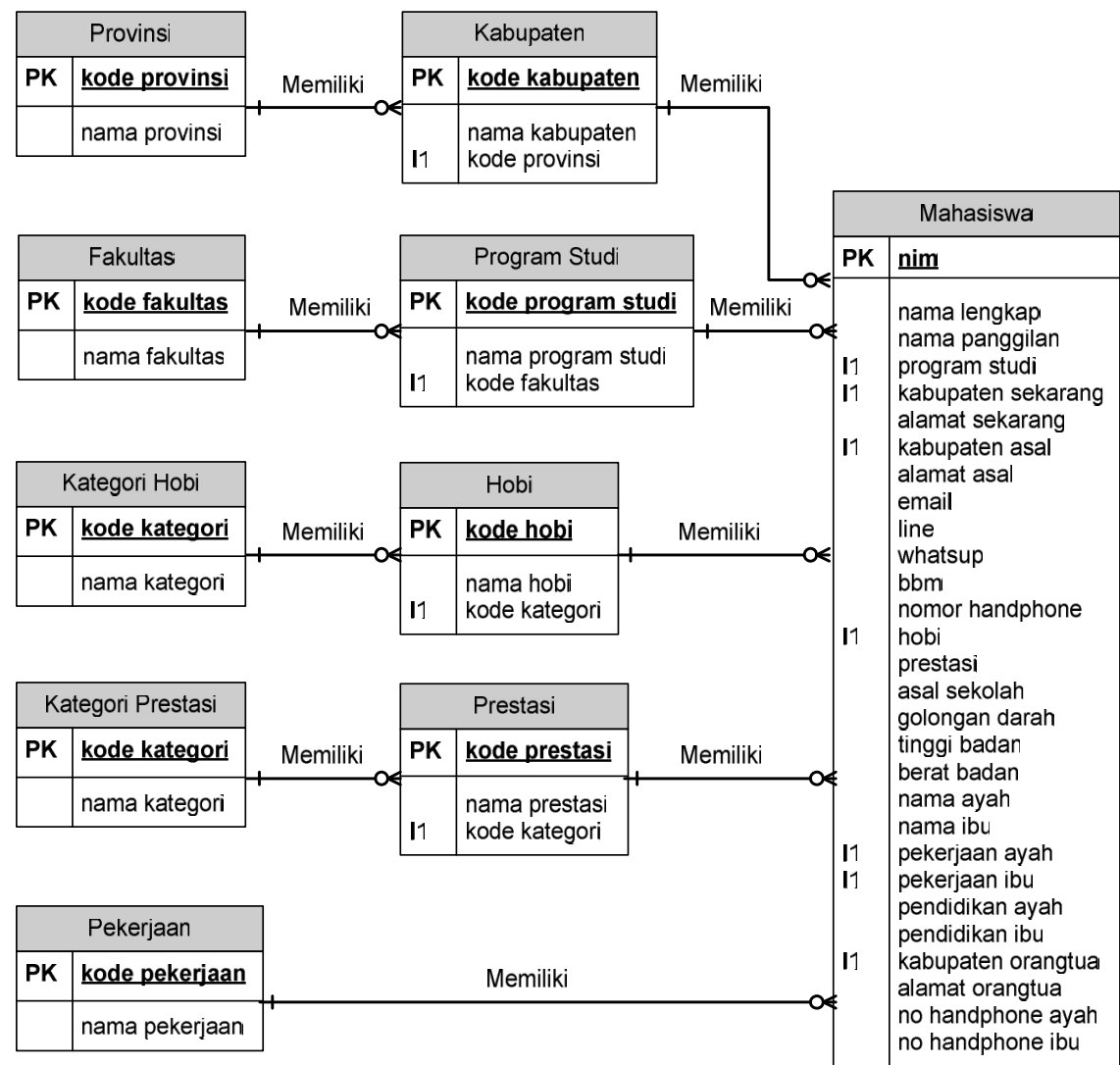

\section{Gambar 6 Model Data Konseptual Sistem Analisis Data Mahasiswa}

Modeldata konseptualpada Gambar 6diatasmenunjukkanatributdari masingmasing

obyek,hubunganobyek,primaryidentifieryan g secaraunik mengidentifikasi obyek serta mandatoryyangmenyatakan atribut harus berisi

data

(tidakbolehkosong).Hubunganyang

terjadiantaraobyekprovinsidenganobyek

kabupatendanobyekkabupatendenganmahasi swaadalahhubunganyang nonspesifik (hubunganmany-to-many). Menurut Whitten etal(2004), hubungannonspesifik tersebut hanyasesuai untuk model data awal danharus dipecah.

\section{Perancangan Antarmuka Pengguna}

Pada sub bab ini peneliti akan menampilkan perancangan antarmuka pengguna dari sistem analisis data mahasiswa.

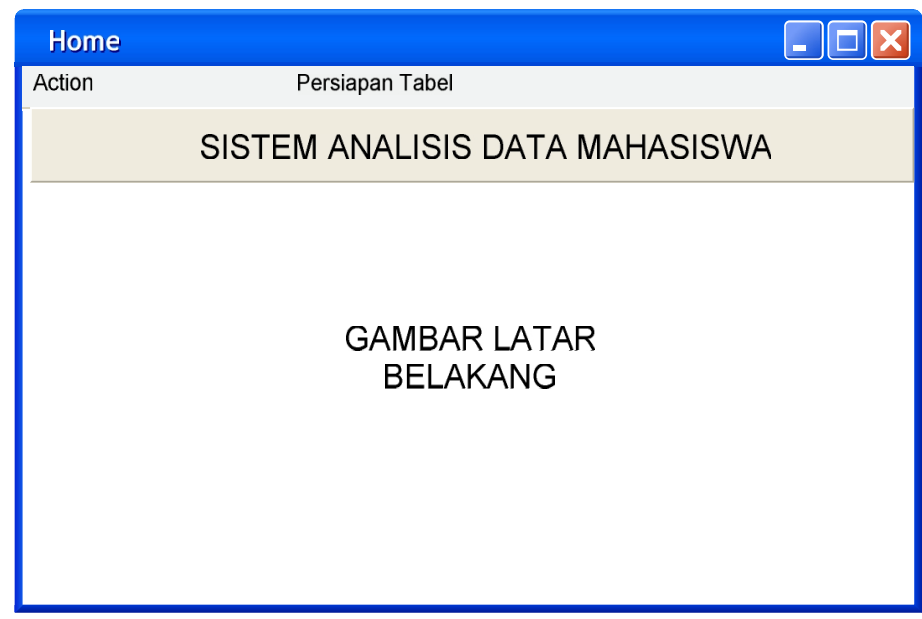

Gambar 7 Form Depan 
Gambar 7 adalah perancangan untuk tampilan depan saat aplikasi pertama kali dijalankan/dieksekusi. Form ini akan tampil pada layar monitor pengguna. Pada tampilan depan terdapat 2 menu utama yaitu : Action dan Persiapan Tabel. Kemudian terdapat judul aplikasi pada bagian atas tepatnya dibawah menu utama yaitu "Sistem Analisis Data Mahasiswa".Pada bagian tengah kebawah terdapat gambar latarbelakang yang memiliki tulisan "Selamat Datang".

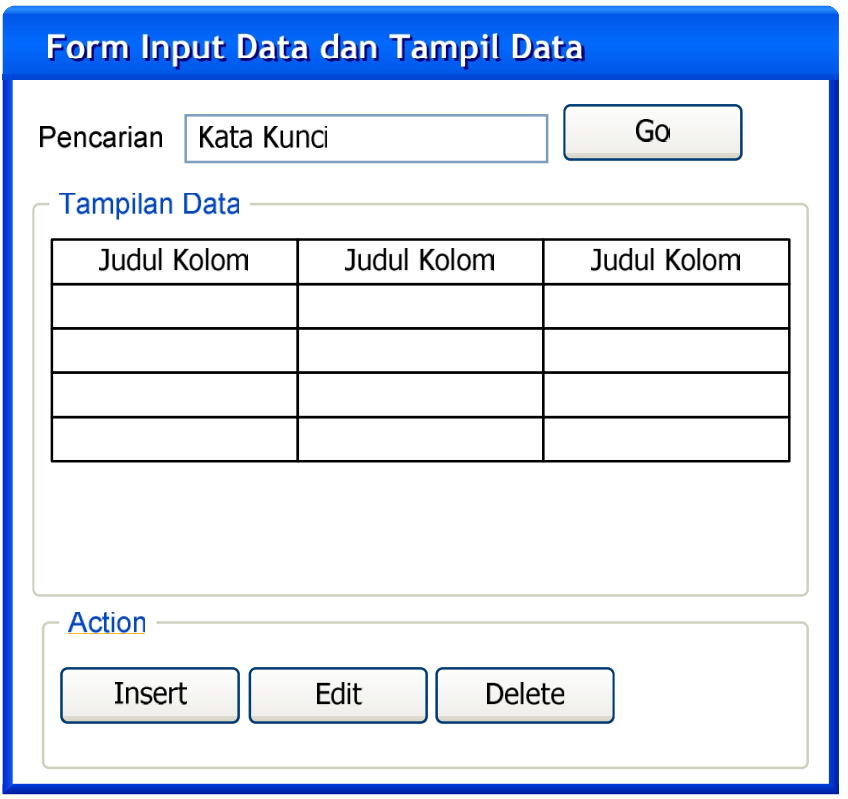

Gambar 8 Form Input dan Tampil Data

Gambar 8 adalah perancangan form untuk memasukkan data baru dan menampilkan hasilnya pada layar monitor pengguna. Pada form ini terdapat area untuk melakukan pencarian data berdasarkan kata kunci yang diinput oleh pengguna dimana letaknya pada bagian atas. Pada bagian tengah terdapat sebuah tabel yang berfungsi untuk menampilkan semua data atau hasil pencarian data.Dan pada bagian bawah

terdapat beberapa tombol yang memiliki fungsi berbeda. Tombol yang bertuliskan insert memiliki fungsi untuk memasukkan data baru ke basisdata. Tombol bertuliskan edit berfungsi untuk mengubah sebagian data yang dipilih dari tabel diatasnya. Tombol bertuliskan hapus berfungsi untuk menghapus data dari basisdata secara permanen.

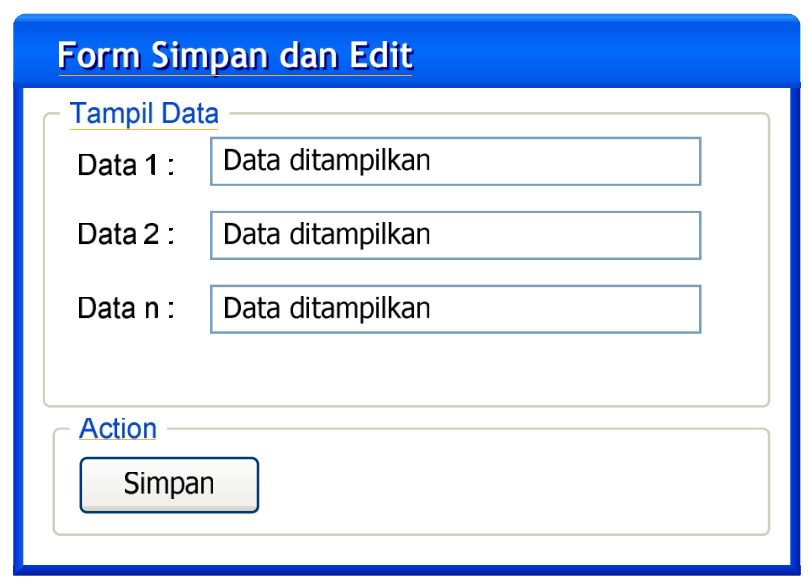

Gambar 9 Form Simpan dan Edit

Gambar 9 menampilkan perancangan form yang digunakan untuk melakukan edit data dan simpan data baru. Pada form ini terdapat satu tombol dan beberapa textbox.
Satu tombol tersebut adalah tombol simpan yang digunakan untuk menyimpan data ke basisdata. Beberapa textbox digunakan untuk menampilkan data jika pengguna 
melakukan edit data dan apabila pengguna melakukan input data baru maka textbox digunakan untuk memasukkan data baru.

\section{SKENARIO UJI COBA}

Tahap ini dilakukan perancangan desain sistem yang meliputi : Penentuan lokasi penelitian, pengumpulan data, pembuatan basis data, analisis kebutuhan sistem, analisis kebutuhan user, desain antarmuka sistem dan pengkodean.

- Penentuan lokasi penelitian: Penelitian dilakukan pada Universitas Dhyana Pura Jalan Raya Padang Luwih Br. Tegaljaya, Dalung, Kuta Utara Badung Bali 80361.

- Pengumpulan data: Data mahasiswa yang digunakan adalah data yang bersumber dari Kantor LPPM Undhira pada tahun 2015.

- Pembuatan basis data: Basis data dirancang dengan metode normalisasi berdasarkan data mahasiswa yang diberikan.

- Analisis kebutuhan sistem: Sistem ini dibangun untuk membantu proses analisamahasiswa menjadi lebih mudah dan meningkatkan pelayanan kepada masyarakat. Oleh karena itu sistem ini membutuhkan data biodata mahasiswa, program studi untuk masing - masing mahasiswa, fakultas.

- Analisis kebutuhan user: Dalam pelaksanaan penelitian yang akan dilakukan peneliti hanya mengembangkan sistem untuk membantu pihak pegawai pada kantor LPPM dalam hal proses analisa terhadap mahasiswa. Dalam wawancara dengan Kepala LPPM memerlukan sebuah sistem dengan kriteria sebagai berikut : 1). Sistem dapat melakukan analisa data mahasiswa dari biodata mahasiswa. 2). Sistem dapat membuat laporan hasil analisa untuk setiap angkatan. 3). Sistem dapat digunakan secara bersama - sama.

- Desain antarmuka sistem: Berdasarkan rancangan sistem kemudian dibuat antarmuka aplikasi dengan menggunakan bahasa pemrograman delphi.

- Pengkodean: Berdasarkan rancangan sistem kemudian dicodingkan dengan menggunakan bahasa pemrograman delphi.

\section{HASIL UJI COBA \\ Hasil Penelitian Sementara}

Pada bab ini akan diuraikan mengenai hasil perancangan sistem informasi analisis data mahasiswa yang sudah dirancang pada bab sebelumnya. Pengujian dilakukan untuk mengetahui apakah sistem yang dibangun dapat memenuhi kebutuhan pengguna untuk melakukan analisis.

Proses pertama adalah mempersiapkan data-data utama yang diperlukan sewaktu menginput data mahasiswa. Adapun data-data yang dimaksud adalah data fakultas, data program studi, data provinsi, data kabupaten, data pekerjaan, data prestasi dan data hobi. Data ini juga merupakan data yang akan dianalisis oleh pengguna karena itu ketersediaan data ini sangat penting.

Proses kedua adalah melakukan pemeriksaan hubungan antar tabel. Pemeriksaan ini dilakukan untuk mengetahui apakah semua tabel sudah terhubung dengan baik. Pemeriksaan dilakukan dengan melakukan query ke basisdata. Hubungan antar tabel merupakan kunci utama agar hasil analisis sesuai dengan harapan pengguna.

Proses ketiga adalah melakukan input biodata mahasiswa. Data diinput langsung ke basisdata melalui query dan juga untuk mengetahui apakah data-data utama yang sudah disiapkan dapat berfungsi dengan baik. Setelah dilakukan input biodata mahasiswa maka selanjutnya akan dicoba melakukan analisis seperti mengetahui jumlah mahasiswa yang memiliki golongan darah $\mathrm{A}, \mathrm{B}, \mathrm{AB}$, dan $\mathrm{O}$ dari masing-masing program studi.

\section{Data Pengujian}

Data yang digunakan dalam penelitian ini adalah data mahasiswa Universitas Dhyana Pura.Dimana data yang digunakan adalah data mahasiswa angkatan 2015/2016.

\section{Skenario Pengujian}

Skenario pengujian pertama adalah mengukur kinerja sistem yang dirancang dalam melakukan analisis data kemudian dibandingkan dengan kinerja secara konvensional.Apabila hasil yang didapatkan bahwa sistem mampu memberikan hasil analisis lebih cepat dan akurat maka sistem ini layak untuk diterapkan secara penuh. 
Skenario pengujian kedua adalah menggunakan sistem ini untuk menggantikan form cetak yang biasa digunakan mahasiswa untuk mengisi biodata. Apabila hasil yang didapatkan tetap atau meningkat dalam hal kenyamanan dan efisiensi maka sistem ini layak untuk menggantikan cara pengisian biodata konvensional.

\section{SIMPULAN}

Berdasarkanpenelitianyangsudahdilakukansa mpai tahapan kuranglebih $70 \%$ dari system yang akan dibangun mengenai Sistem Analisis Data Mahasiswa, maka dapat diambil kesimpulan sebagai berikut:

- Pemodelan Sistem Analisis Data Mahasiswa dalam meningkatkan kualitas pelayanan dapat dilakukan perancangannya dengan berbasis Client-Server.

- Analisis data dapat dilakukan dengan lebih cepat dan fleksibel.

- Data dapat disimpan dengan lebih aman dan terstruktur.

- Dapat menggantikan cara pengisian biodata secara konvensional sehingga mengurangi penggunaan kertas.

\section{DAFTAR PUSTAKA}

[1] Hartono Jogiyanto, MBA, Ph.D., 1999, Pengenalan Komputer, Andi, Yogyakarta

[2] Husni, 2004, Pemrograman Database Dengan Delphi, Graha Ilmu, Yogyakarta.

[3] Kadir Abdul, 2003, Konsep dan Tuntunan Praktis Basis Data. Andi, Yogyakarta.

[4] Kadir Abdul, 2003, Pengenalan Sistem Informasi. Andi, Yogyakarta.

[5] Pressman Roger S, Ph.D., 2002, Rekayasa Perangkat Lunak Pendekatan Praktisi (Buku Satu), Andi, Yogyakarta.

[6] Wahana Komputer, 2003, Pengembangan Aplikasi Client/Server dengan Borland Delphi, Elex Media Komputindo, Jakarta.

[7] Wahana Komputer, 2005, Membuat Program Kreatif dan Profesional dengan Delphi, Elex Media Komputindo, Jakarta. 